\title{
Assessing the Impact of Industrial Policies on Economic Development in Nepal
}

\author{
Khom Raj Kharel, Ph.D.*
}

\begin{abstract}
This study analyzes the impact of industrial policies on Nepalese economic development. For this, simple regression model has been applied to estimate the impact of industrial policies on macroeconomic growth. The impact of industrial policies is analyzed as pre-liberalization period (1974/75-1991/92), post liberalization period (1991/92-2009/10) and whole period (1974/75-2009/10). The result shows that there are significant positive relationship between economic openness and industrial registration, GDP, industrial GDP, employment, investment, foreign trade (imports and exports), trade balance, total revenue and trade tax in the whole of 1974/752009/10. During pre-liberalization period, these relationships have also been found positive, as well. But, during the post liberalization period, the impact of economic openness on the growth of industries, GDP, employment, investment, total revenue, trade tax, total trade, import trade, export trade and trade balance are not found positive. To achieve the satisfactory result the government policies should be appropriately reviewed to make them investment friendly and accelerate the industrial development in Nepal.
\end{abstract}

Key words: Industrial policy, impact, Nepal, pre- and post liberalization periods, economic growth

\section{BACKGROUND}

Industrial policies play crucial roles for the macroeconomic development of the country. The world experiences show that some countries are in the position of high income group due to rapid industrialization. Macroeconomic variables such GDP, employment, investment, foreign trade, total revenue, and trade balance as well influence granted to the economic openness and industrial policy change. The new emerging countries had adopted import substitution policy before 1980s and then they applied export promotion industrial policy.

Nepal has adopted protectionist regime during 1956-85 and then towards an open, liberal regime from 1985/86. Industrial investment was regulated by means of a rigorous licensing system; domestic industries were protected from foreign competition in the forms of high tariffs and quantitative restrictions, licensing system in imports

\footnotetext{
* Dr. Kharel is Lecturer of Economics at Saraswoti Multiple Campus, Tribhuvan University, Nepal
} 
of intermediate inputs and restrictions in the use of foreign exchange. This regime virtually had negative impact on industrial growth and poor performance. Against this background liberalization reforms were introduced in 1985/86. Nepal pursued a gradual liberalization by dismantling Quantitative Restrictions (QRs) and simplifying the industrial licensing regime, gradually reducing tariffs, etc. The industrial licensing regime and foreign investment procedures have been substantially liberalized since the mid 1980s. In fact, Nepal had also applied import substitution industrial policy before 1990s, and then she applied export promotion policy.

This study is undertaken to analyze the impact of industrial policies in the economic development of Nepal. For this, the impacts of industrial policies on economic development have been analyzed by assessing the relationships between different macroeconomic variables such as GDP, industrial GDP, investment, total trade, trade balance, total revenue, trade tax, number of registration of industries, employment as dependent variables and economic openness has been proxied by Economic Openness Index (EOI) as independent variable.

\section{RESEARCH PROBLEM AND OBJECTIVE}

Most of the countries in the world have implemented various industrial policies and Acts in order to protect national industries and promoted industrial development and economic growth. Industrial policies have been widely and successfully used in the world, especially in the centrally planned economies. Many studies found that the existing policies of Nepal could not address the issue of creating linkages through appropriate incentive package which could encourage the growth of primary and intermediate goods and support services, induced by the setting up of manufacturing units or service units in the country. Foreign investment is regarded as an important source of investment, technology and market access. In spite of this, Nepal has not succeeded in attracting the required quantum of investment and technology. Government of Nepal has brought different policies related to industrial development time and again, but the result is not satisfactory.

Despite implementation of different policies in different periods, the impact of these policies in industrialization has neither been adequately studied nor evaluated properly. Since a significant number of studies are on the overall relationship between industrialization and economic growth, there is dearth of comprehensive study on industrial policies adopted by Government of Nepal and its impact on economic development. The present study is basically necessary to assess the impact of industrial policies on economic growth, employment, investment, trade.

On this background the overall objective of this study is to analysis the impact of industrial policies on economic development of Nepal with special focus on industrial 
growth, GDP, industrial GDP, investment, foreign trade, total revenue and trade balance of the country.

\section{LITERATURE REVIEW}

Industrial policy, in a common parlance, is that which government-sponsored economic program in which the public and private sectors coordinate their efforts to develop new technologies and industries. Government provides the financial support and capital to the private sector by direct subsidies, tax credits, or government-run developmental banks. Industrial policy emphasizes cooperation between government, banks, private enterprise, and employees to strengthen the national economy.

In the 1980s and 1990s, industrial policies were enjoyed some success in Germany and Japan. In the United States, such direct government involvement in business planning had traditionally been viewed with suspicion. Industrial policies were sector specific, unlike broader macroeconomic policies. Examples of horizontal, economy wide policies were tightening credit or taxing capital gain, while examples of vertical, sector-specific policies comprise protecting textiles from foreign imports or subsidizing export industries (Rodrik, 2009). Literatures on industrial development suggest that success and failure of industrial policies are equally compelling. Since similar policies may work well in one place and not in another, the policy making is basically contextual. Thus, the choice of industrial specialization and policies that go with it is more or less unique to individual country circumstances (Haque, 2007).

Three arguments in favor of industrial policy have received the most attention. The first is derived from the presence of knowledge spillovers and dynamic scale economies; the second steps from the presence of coordination failures while the third concerns informational externalities (Pack\&Saggi, 2006). This argument assumes that production costs for newly established domestic industries in a country may be initially higher than those of well-established foreign competitors due to their greater experience. Due to the initial absence of experience, if domestic industry is not protected from foreign competition, it will never take off and if dynamic scale economies are strong enough, temporary protection of the domestic industry can be in the national interest. The basic idea behind the coordination failure argument for industrial policy is that many projects require simultaneous investments in order to be viable and if these investments are made by independent agents there is little guarantee that, acting in their own self interest, each agent would choose to invest.

Analyzing the data of 45 developing countries, Bjorvatn and Coniglio (2007) show that broad based policies have a positive impact in growth only in relatively open economies. In less open economies, interventionist policies are associated with stronger growth. 
Similarly, the data shows that reducing the direct involvement of the government in markets, for instance through deregulation and/or privatization, has a positive effect on growth only in relatively open economies. Indeed, in relatively closed economies, such policy reforms are associated with slower economic growth.

Making an explicit comparison between the strategies adopted in East Asia and Latin America, Shapiro (2007) reviews the impact of industrial policy on growth in developing countries from the 1960s. She highlights how the rationales and instruments of industrial policy have changed since the 1960s. She finds that theories of industrialization have come full circle, as many of the assumptions behind the market failure paradigm have made a comeback. The policy implications of these theories, however, have not been similarly resurrected. Ocampo (2007) suggests three important dimensions to be reflected on industrial policies in developing countries: innovations (in a Schumpeterian sense), linkages (Hirschman), and surplus labour (Lewis). There are two elements that must be taken into account in understanding the links between industrial policies and growth. The first is that domestic factors are not the sole determinant of domestic policies. The regional and global economic environments are also essential determinants of growth, an issue usually overlooked in the massive literature on economic growth in recent decades.

Discussing industrial policies of various countries, Robinson (2009) made five arguments. First, from a theoretical point of view there are good grounds for believing that industrial policy can play an important role in promoting development. Second, there certainly are examples where industrial policy has played this role. Third, for every such example there are others where industrial policy has been a failure and may even have impeded development. Fourth, the difference between these second and third cases rests in the politics of policy. Fifth, to really promote industrialization in a society we need a positive theory of the political equilibrium of that society which leads to particular policy choices. To give policy advice that would foster industry, one has to understand this political equilibrium and either attempt to change it or work within the environment it generates.

The evidence on unsuccessful industrial policy is equally compelling. This suggests that neither extreme view is correct. Industrial policy can sometimes work, but sometimes not. Robinson (2009) argues that Industrial policy has been successful when those with political power who have implemented the policy have either themselves directly wished for industrialization to succeed, or been forced to act in this way by the incentives generated by political institutions. He suggests stop thinking of normative industry policy and instead begin to develop a satisfactory positive approach to help poor countries to industrialize. Drawing conclusion, Robinson suggests that failed 
industrial policy, like bad policy more generally, is the consequence of perverse political incentives. The successful promotion of industry therefore requires changes in the political equilibrium in such a way as to align the incentives of the political powerful with those of society. This may be achieved by changes in political institutions or it may be achieved by endogenous changes in the balance of de facto power in society.

As globalization spreads across the world, the concerns about the industrial competitiveness of developing countries and poverty alleviation are becoming ever more important. Developing countries like Nepal face intense pressure from foreign multinational firms, and in the face of such pressure, Nepal is unable to successfully cope up with the twin goals of market liberalization and promotion of industrial capacity. Effective industrial policies are highly mutable and dependent on the specific circumstances of the country in question. Import substitution policies that were designed to provide protection for the domestic 'Infant' industries, increase savings and investment and to follow the planned development process. The governments of developing countries intervened in various areas of the economy to promote industrialization, particularly in the import-competing sectors, and trade policies were among the most directly affected. The chief effects on trade policy were the restriction on imports. The restriction took various forms in different countries, and many countries employed multiple forms to further their development objective (Krueger, 1980).

By the 1970s, many policy makers and economists found an attractive alternative approach to IS for development in the success stories of South Korea and Taiwan. The success stories of (Southeast) Asian countries were well-documented, appreciated and admired. Of particular interest to other developing countries was the fact that the growth rates of South Korea and Taiwan showed a positive "jump" in the 1960s compared to the 1950s. Other developing countries did not record this jump, though they did experience modest growth. In Taiwan the growth rate increased from about 6.5 percent in the 1950s to more than 10 percent in the 1960s, and in Korea the figure rose from 4.4 percent to 9.1 percent (Bruton, 1998). These two countries also recorded employment growth and progress in alleviating poverty.

The success of Taiwan and Korea changed many ideas used to support IS policies. In contrast to IS policies, export-oriented or export-neutral policies facilitated the growth in exports and as a result, the utilization of the available resources in the countries (Bhagwati \& Krueger, 1973). The strong exports sector also seemed to prevent balance of payment problems. Exports of manufactured goods took off proving that developing countries need not forever hold comparative advantage over only primary commodities. In short, the success of these countries provided the rationale, through 
counter-example, to question many instruments of IS policies, particularly the emphasis laid on the production of import-competing goods, protection of domestic industries that produced such goods, and the practice of exchange rate controls to deal with the balance of payment problems.

Export-oriented development strategy entailed at least an "equal" treatment of exports and the removal of biases against exports under an "IS" regime. Thus, as a result of the reforms, countries abandoned the interventions designed to foster importcompetition. This was achieved in multiple stages - quantitative restrictions were converted into tariffs, tariffs were made more focused, and tariffs themselves were gradually decreased. In general, an "EP" regime is more successful because exporting firms have to face the international market. The policies of individual developing countries cannot create enough distortion in the international market to make certain industries or products more competitive. As exporting firms essentially face a much bigger market than just the domestic market, they enjoy the benefit of being able to utilize economies of scale and other factors that would optimize their output. There is also a substantial potential for growth of these firms.

In the context of Nepal, before 1985 policies were guided by inward looking protectionist strategies. Domestic industries were treated as 'infant industries' and were protected from foreign competition by high tariff and quota restrictions. The government was directly involved in the economy and provided essential products and services. Liberalization initiated in 1985 and accelerated after the 1990s, sought to modernize the economy and accelerate structural changes by creating an environment appropriate for private sector participation. The liberalization policies of 1985 were aimed at correcting that weakness by introducing competitive market conditions through liberalizing trade restrictions and relaxing controls on foreign equity participations. The major part of the liberalization attempt in Nepal concentrates on industries that produce goods for mass consumption. The purpose of these liberalization policies was to development industries based on comparative advantage, efficiency, better capacity utilization, modernization and technology utilization (Regmi, 1994).

Industrial Policy 1987 (Government of Nepal, the then His Majesty's Government,1987) was announced with the objectives of increase self-reliance by producing goods meeting basic needs, change the structure of the national economy by increasing the contributions of industry to national production and to uplift the living conditions of the people, create maximum opportunities of employment in the industrial sector and thus transfer surplus man-power development on agriculture and improve the balance of payment position through import substitution and export promotion. There was the 
provision of licensing system which was assumed to be principal instruments which translate industrial priorities and targets into concrete capacity in the economy.

The Industrial Policy 1992 (Ministry of Industry, 1992) followed outward-looking economic policies. As a result, the private sector was the dominant player in the economy. The Government, in addition to adopting private sector friendly policies, had launched several measures to enhance industrial development such as providing financial, procedural and other concessions to the industries, accorded high priority to Foreign Direct Investment(FDI), and focused to create investment friendly environment. It had enacted Industrial Enterprise Act, Foreign Investment and Technology Transfer Act, Company Act, Privatization Act and incorporated many other related legal provisions in different Acts (GON/SDC, 2002). The Foreign Investment and Technology Transfer Act (FITTA) 1992, the Industrial Enterprises Act 1992 and the Privatization Act 1994 (Government of Nepal, 1994) were the foundation for the increased role of the private sector in the industrial development. Another new industrial policy was adopted in 2010 (Ministry of Industry, GON 2010). This policy was the most liberal industrial policy so far. The policy has also expected that industrial growth will bring down the poverty level in the country. Though it does not scientifically clear that how much percentage of industrial growth will bring down how much percentage of poverty will be reduced.

From the works reviewed it is justified that industrialization is necessary for overall development of a country, and industrial policies are instrumental for creating industrial investment environment of the country. In such a context, whatever the policies, provisions, programs and strategies were set in different plan periods and industrial policies, Nepalese industrial development is not satisfactory. The contribution of industrial sector in national income, employment generation, and export trade is very low.

\section{RESEARCH GAPS}

There are plenty of studies devoted to find the impact of government's policies on industrial development. These studies have concluded the government's policies have played very important role in shaping industrial development in the country. In many cases these policies have contributed to industrial development and as result, uplift socio-economic status of the people. But, other studies have found negative results in this regard. The policies have not helped the growth of basic manufacturing activities that could have multiplier effects on the industry sector at large. Similarly, the policy could not address the issue of creating linkages through appropriate incentive package which could encourage the growth of primary and intermediate goods and support services, induced by the setting up of manufacturing units or service units in 
the country. Foreign investment is regarded as an important source of investment, technology and market access. In the case of Nepal, the government has brought different policies related to industrial development time and again, but the result is not satisfactory. Nepal is still far behind in industrialization. Most of these studies focus on the overall relationship between industrialization and economic growth. Studies on Nepalese context focus on impact of liberalization on economic development. These studies have not adequately addressed the problems of low industrial development in Nepal. There is dearth of comprehensive study on industrial policies adopted by Government of Nepal and its impact on economic development.

\section{RESEARCH METHODOLOGY}

\section{Research Design}

This study is the descriptive and analytical in nature. So the descriptive and analytical research design has been applied. In case of descriptive research design, different tables, diagram and examples has been presented in the different chapter as necessary. Similarly, different econometric and statistical tools and models have been used to measure the impact of different policies on different macroeconomic parameters that are linked to the economic development of Nepal with special focus on Nepalese industrialization.

A separate master table of the determinants of the industrial policies using the dummy variable and the Economic Openness Index (ratios of total trade to GDP -TOI) is constructed. For analyzing and interpreting the data collected through different sources in the process of presentation and analysis, quantitative methods have been applied with the help of Excel (Microsoft Office Excel 2007), EVIEWS (3.0 version). The tables, graphs and diagrams have also been presented.

\section{Data Sources and Analysis Procedures}

The essential data for this study were gathered from the publications of Department of Industry and Ministry of Finance, Government of Nepal. For the parametric analysis part of the study, comparable set of data for the period 1974/75 to 2009/10 were used. To examine the holistic view on the impact of industrial policies on the economic development as well as industrialization in Nepal, simple regression analysis is employed in double log and semi- $\log$ linear models. The macroeconomic variables used in this study are regressed on economic openness index (EOI) and dummy variable as independent variables to represent the industrial policies. The following equations are used to estimate the impact of industrial policies on different macroeconomic variables of Nepalese economy both in pre- and post liberalization periods: 
$\operatorname{lnINDUSGDP} P_{t}=\alpha_{0}+\beta_{1} E O I_{t}+e_{1 t}$

Where, lnINDUSGDP is the natural log of industrial registration, EOI (economic openness index) is economic openness index. The $\alpha_{0}$ is constant, and $\beta_{1}$ is coefficients parameter.

The impact of industrial policy on the industrial employment is estimated by:

$\operatorname{lnINEMPL} L_{t}=\alpha_{0}+\beta_{1} E O I_{t}+e_{2 t}$

Where, lnINEMPL is the natural log of industrial employment.

The impact of industrial policy on the GDP is estimated by:

$\operatorname{lnINGDP} P_{t}=\alpha_{0}+\beta_{1} E O I_{t}+e_{3 t}$

Where, lnINGDP is the natural log of GDP.

The impact of industrial policy on the industrial GDP is estimated by:

$\operatorname{lnINGDPID}{ }_{t}=\alpha_{0}+\beta_{1} E O I_{t}+e_{4 t}$

Where, lnINGDPID is the natural log of industrial GDP.

The impact of industrial policy on gross investment is estimated by:

$\operatorname{lnININVEST}_{t}=\alpha_{0}+\beta_{1}$ EOI $_{t}+e_{5 t}$

Where, lnININVEST is the natural log of gross investment.

The impact of industrial policy on total import is estimated by:

$$
\operatorname{lnINIMPORT} T_{t}=\alpha_{0}+\beta_{1} E \mathrm{EI}_{t}+e_{6 t}
$$

Where, lnININPORT is the natural log of total import.

The impact of industrial policy on total export is estimated by:

$$
\operatorname{lnINX} X_{t}=\alpha_{0}+\beta_{1} E O I_{t}+e_{7 t}
$$

Where, $\operatorname{lnINX}$ is the natural $\log$ of total export.

The impact of industrial policy on total trade is estimated by:

$$
\operatorname{lnINTRADE} E_{t}=\alpha_{0}+\beta_{1} E O I_{t}+e_{8 t}
$$

Where, lnINTRADE is the natural log of total trade.

The impact of industrial policy on trade balance is estimated by:

$$
\operatorname{lnINTBAL_{t}}=\alpha_{0}+\beta_{1} E O I_{t}+e_{9 t}
$$


Where, lnINTBAL is the natural log of trade balance.

The impact of industrial policy on trade revenue is estimated by:

$$
\operatorname{lnINTT}_{t}=\alpha_{0}+\beta_{1} E O I_{t}+e_{10}
$$

Where, lnINTT is the natural log of total trade revenues.

The impact of industrial policy on total tax revenue is estimated by:

$$
\operatorname{lnINTR}{ }_{t}=\alpha_{0}+\beta_{1} E O I_{t}+e_{11 t}
$$

Where, lnINTR is the natural log of total tax revenues.

In specifications (1) through (11) the $\mathrm{e}_{\mathrm{i}} \mathrm{s}$ are are the error terms.

For analyzing and interpreting the data collected through different sources in the process of presentation and analysis, both the qualitative and quantitative parameters have been used. Required mathematical, accounting, and statistical tools as well as econometrics tools and techniques were applied. The tables, graphs and diagrams were prepared; simple percentage, regression, time rate of growth, and tables were presented.

\section{EMPIRICAL RESULTS AND DISCUSSION}

Present study attempts to investigate the impact of industrial policies on the economic development of Nepal. The impact is especially assessed from the overall examination of the industrial polices. Most of the data and information of the study are concerned with past phenomena of the performance. After the collection of data and experiences, this study used analytical as well as descriptive research design. Standard statistical, mathematical tools have been used to measure the impact of industrial policy on the industrialization practices and economic development.

To analyze the impact of industrial policies on economic development of Nepal, various study documents have reviewed. Basically, the impact of industrial policies on economic development has analyzed as pre-liberalization and post liberalization period. Similarly, the impact has also been analyzed as policy changes. Shapiro (2007) explains the impact of IP on growth of developing through the descriptive methods. By reviewing the various study reports, research articles and documents, in this study, descriptive and analytical/quantitative techniques have been used to analyze the impact of industrial policies on Nepalese economy.

\section{Linkages between Industrial Policies and Macroeconomic Variables}

For this, the impacts of industrial policies on economic development have been analyzed by assessing the relationships between different macroeconomic variables 
such as industrial growth, employment, GDP, industrial GDP, investment, total trade, trade balance, total revenue, trade tax as dependent variables and economic openness has been proxied by Economic Openness Index (EOI) as independent variable. The impact is analyzed dividing the time periods as pre-liberalization, post-liberalization and whole time period.

\section{Impact on Industrial Growth}

Empirical evidence shows that liberalization has positive impact on industrial development in Nepal. By using data of 1974/75-1991/92, this study finds that the relationship between Economic Openness Index (EOI) and growth of industries is positive. In the regression analysis, the relationship has been analyzed between the natural log of number industries (lnINDUS) and economic openness index (EOI = 0.3016). The result seems to be valid as all diagnostic parameters justify the relationship such as the regression coefficient is significant at 1 percent $t$-value (critical value) with coefficient $0.83\left(R^{2}=0.83\right)$. It indicates that there is significant impact of economic openness on the number of industries registered (Table 1).

Table 1: Regression between the Number of Industries Registered and Economic Openness in Pre-liberalization Period (1974/75-1991/92)

Dependent variable is lnINDUS

\begin{tabular}{lllll}
\hline Variables & Coefficient & Std. Error & t-Statistic & Prob. \\
\hline EOI & 0.301633 & 0.034881 & 8.647414 & 0 \\
C & -3.27087 & 0.730308 & -4.478757 & 0.0004 \\
R-squared & 0.832921 & Mean dependent var & 2.997059 \\
Adjusted R-squared & 0.821782 & S.D. dependent var & 0.871771 \\
S.E. of regression & 0.368026 & Akaike info criterion & 0.948802 \\
Sum squared resid & 2.031642 & Schwarz criterion & 1.046827 \\
Log likelihood & -6.06482 & F-statistic & 74.77777 \\
Durbin-Watson stat & 1.474489 & Prob(F-statistic) & 0 \\
Included observations: 17 & & & \\
\hline
\end{tabular}

Source: Estimated by the author based on Appendix-I and II.

However, this relationship is found to be opposite in the post liberalization period 1991/92-2009/10). The analysis shows that there is no relationship between economic openness and industrial registration in the post-liberalization period as the diagnostic $\mathrm{t}$-value is found to be insignificant. It means, there is no impact of economic openness on the growth of the industry in post liberalization period. This may be justifiable because Nepal had to go through much political instability, making uncertainty in government policy and deteriorating investment climate due to labour unrest, insecurity, etc.(Table 2). 
Table 2: Regression between the Number of Industries Registered and Economic Openness in Post-liberalization period (1991/92-2009/10)

Dependent Variable: InINDUS

\begin{tabular}{lllll}
\hline Variables & Coefficient & Std. Error & t-Statistic & Prob. \\
\hline EOI & -0.05148 & 0.043824 & -1.174796 & 0.2563 \\
C & 7.109622 & 1.592074 & 4.465635 & 0.0003 \\
R-squared & 0.075089 & Mean dependent var & 5.244211 \\
Adjusted R-squared & 0.020682 & S.D. dependent var & 0.509873 \\
S.E. of regression & 0.504572 & Akaike info criterion & 1.56909 \\
Sum squared resid & 4.328087 & Schwarz criterion & 1.668505 \\
Log likelihood & -12.9064 & F-statistic & 1.380145 \\
Durbin-Watson stat & 1.027578 & Prob(F-statistic) & 0.25627 \\
Included observations: & 19 & & \\
\hline
\end{tabular}

Source: Estimated by the author based on Appendix-I and II.

Analyzing the data of $1974 / 75-2009 / 10$, this study finds that there is a significant positive relationship between economic openness and industrial growth, indicating openness has increased the number of industries registered. The result seems to be valid as all diagnostic parameters justify the relationship such as the regression coefficient is significant at 1 percent $t$-value with coefficient $0.77\left(R^{2}=0.77\right)$. The result can be interpreted that there is significant impact of economic openness on the number of industries registered during the whole period (Table 3).

Table 3: Regression between the Number of Industries Registered and Economic Openness Index during 1974/75 to 2009/10

Dependent Variable: lnINDUS

\begin{tabular}{lllll}
\hline Variables & Coefficient & Std. Error & t-Statistic & Prob. \\
\hline EOI & 0.141771 & 0.013222 & 10.72231 & 0 \\
C & 0.080844 & 0.397443 & 0.20341 & 0.84 \\
R-squared & 0.771763 & Mean dependent var & 4.183056 \\
Adjusted R-squared & 0.76505 & S.D. dependent var & 1.332518 \\
S.E. of regression & 0.645893 & Akaike info criterion & 2.017588 \\
Sum squared resid & 14.18406 & Schwarz criterion & 2.105561 \\
Log likelihood & -34.3166 & F-statistic & 114.9679 \\
Durbin-Watson stat & 0.554866 & Prob(F-statistic) & 0 \\
Included observations: 36 & & & \\
\hline
\end{tabular}

Source: Estimated by the author based on Appendix-I and II. 


\section{Impact on Employment}

Employment creation is the main criterion for the economic policy. Economic policies and other sectoral policies of the Government of Nepal articulate these sentiments. These policies and programs have indentified number of job drivers, led by industry, which can create substantial employment. It proposes both sectoral interventions and a package of macro-economic and micro-economic policies designed to ensure that the economy becomes both more competitive and more employment friendly.

The industrial policy 1992 was based on the principle of bringing the private sector in the forefront of play for industrialization of the country through privatization of the public enterprises, ensuring prevention from nationalization of the private industries and promoting competitiveness and competition among the private industries for reducing the production cost. The main objective of the IP 2010 is to contribute to poverty eradication through promotion of public private sector partnership and broad based industrial growth. It also aims at increasing national income and employment by enhancing export of qualitative and competitive industrial products. The estimates result is summarized in Table 4 .

Table 4: Regression between Employment and Economic Openness during 1974/75 to $2009 / 10$

Dependent Variable: lnEMPL

\begin{tabular}{lllll}
\hline Variables & Coefficient & Std. Error & t-Statistic & Prob. \\
\hline EOI & 0.096903 & 0.01649 & 5.876608 & 0 \\
C & 6.218006 & 0.495663 & 12.54482 & 0 \\
R-squared & 0.5039 & Mean dependent var & 9.021944 \\
Adjusted R-squared & 0.489308 & S.D. dependent var & 1.127181 \\
S.E. of regression & 0.805514 & Akaike info criterion & 2.459279 \\
Sum squared resid & 22.06097 & Schwarz criterion & 2.547252 \\
Log likelihood & -42.267 & F-statistic & 34.53452 \\
Durbin-Watson stat & 0.336335 & Prob(F-statistic) & 0.000001 \\
Included observations: 36 & & \\
\hline
\end{tabular}

Source: Estimated by the author based on Appendix-I and II.

While analyzing data of 1974/75-2009/10, the result of regression analysis shows that there is significant positive impact of economic openness on employment. The relationship between economic openness index (EOI) and employment (EMPL) is positive with coefficient $\mathrm{R}^{2}=0.50$ having significant at 1 percent critical value. This implies that economic openness has created more employment opportunities in Nepal during 1974/75-2009/10 (Table 4). 
The same relationships can be found when data is disintegrated into two time period - pre liberalization and post liberalization periods. The result is more robust in preliberalization period (1974/75-1991/92).The relationship between economic openness index (EOI) and employment (EMPL) is positive with coefficient $\mathrm{R}^{2}=0.84$ having significant at 1 percent critical value. This implies that the increase in economic openness has created more employment opportunities in Nepal during 1974/751991/92 (Table 5).

Table 5: Regression between the Employment and Economic Openness in Preliberalization period (1974/75-1991/92)

Dependent Variable: InEMPL

\begin{tabular}{lllll}
\hline Variables & Coefficient & Std. Error & t-Statistic & Prob. \\
\hline EOI & 0.386918 & 0.044287 & 8.736602 & 0 \\
C & 0.238664 & 0.927236 & 0.257393 & 0.8004 \\
R-squared & 0.835757 & Mean dependent var & 8.278824 \\
Adjusted R-squared & 0.824808 & S.D. dependent var & 1.116361 \\
S.E. of regression & 0.467264 & Akaike info criterion & 1.426285 \\
Sum squared resid & 3.27503 & Schwarz criterion & 1.52431 \\
Log likelihood & -10.1234 & F-statistic & 76.32822 \\
Durbin-Watson stat & 1.214723 & Prob(F-statistic) & 0 \\
Included observations: 17 & & \\
\hline
\end{tabular}

Source: Estimated by the by author based on Appendix-I and II.

\section{Impact on GDP}

All the sectoral policies have been targeted towards this. Nepal followed the same international trend of economic policymaking. Until the mid 1980s, Nepal had an active industrial policy with direct involvement of the government in the economy. Nepal initiated economic liberalization through the implementation of Structural Adjustment Programs (SAPs) in late 1980s and accelerated the process in early 1990s. By this policy, the government withdrew and the private sector took the driving seat in the economy. In 1992, GoN formulated new industrial policy which aimed at privatizing public sector industries and sought to create an open and competitive economy by curtailing government interference. Private sectors involvement was the main thrust of the policy. 
But, impact of liberalization in industrial development is not uniform in different industries and in different areas. Later, Nepalese economy confronted many obstacles hindering its growth. Limiting factors for development have included: an inefficient legal system and extensive regulations like those of the labour market, a low savings rate which has limited capital formation, a minor role for FDI, especially when compared to other countries, lack of access to finance, especially for small business, high tariff levels which restrict competition in domestic markets and hinder the development of potential exporters. The contribution of industrial sector in GDP in during the whole observed period does not cross above 10 percent till now.

Regression analysis shows that there is significant positive relationship between economic openness and GDP during 1974/75-2009/10. The independent variable Economic Openness Index (EOI, 0.147874) is significant at 1 percent critical value with coefficient 0.82 . The coefficient is positive which indicates that the increase in economic openness is related to increase in GDP (Table 6).

Table 6: Regression between GDP and Economic Openness during 1974/75- 2009/10 Dependent Variable: InGDP

\begin{tabular}{lllll}
\hline Variables & Coefficient & Std. Error & t-Statistic & Prob. \\
\hline EOI & 0.147874 & 0.011683 & 12.65702 & 0 \\
C & 7.528973 & 0.351185 & 21.43877 & 0 \\
R-squared & 0.824923 & Mean dependent var & 11.80778 \\
Adjusted R-squared & 0.819774 & S.D. dependent var & 1.344351 \\
S.E. of regression & 0.570718 & Akaike info criterion & 1.770111 \\
Sum squared resid & 11.07447 & Schwarz criterion & 1.858085 \\
Log likelihood & -29.862 & F-statistic & 160.2002 \\
Durbin-Watson stat & 0.371844 & Prob(F-statistic) & 0 \\
Included observations: 36 & & & \\
\hline
\end{tabular}

Source: Estimated by author based on Appendix-III and IV.

The comparison of growth of GDP in the pre-liberalization (1974/1975-1991/92) and post-liberalization (1991/92 - 2009/10) period, the effect of economic openness on GDP is positive and statistically significant in the pre-liberalization period but result is opposite in the post-liberalization period (Table 7). 
Table 7: Regression between GDP and Economic Openness in the Pre-liberalization (1974/75 -1991/92)

Dependent Variable: $\operatorname{lnGDP}$

\begin{tabular}{lllll}
\hline Variables & Coefficient & Std. Error & t-Statistic & Prob. \\
\hline EOI & 0.212455 & 0.033594 & 6.324208 & 0 \\
C & 6.147531 & 0.703356 & 8.740282 & 0 \\
R-squared & 0.727251 & Mean dependent var & 10.56235 \\
Adjusted R-squared & 0.709068 & S.D. dependent var & 0.657129 \\
S.E. of regression & 0.354443 & Akaike info criterion & 0.873595 \\
Sum squared resid & 1.884452 & Schwarz criterion & 0.97162 \\
Log likelihood & -5.42556 & F-statistic & 39.9956 \\
Durbin-Watson stat & 1.279595 & Prob(F-statistic) & 0.000014 \\
Included observations: 17 & & &
\end{tabular}

Source: Estimated by the author based on Appendix-III and IV.

The data analysis of pre-liberalization period shows that there is a significance positive relationship between economic openness and GDP with coefficient 0.72 having significant at 1 percent critical value. The result indicates that openness has increased GDP in the pre-liberalization period, whereas, the relationship between GDP and economic openness in the post liberalization period is statistically insignificant $\left(\mathrm{R}^{2}=\right.$ 00) (Table 8).

Table 8: Regression between GDP and Economic Openness in the Post-liberalization (1991/92 -2009/10)

Dependent Variable: lnGDP

\begin{tabular}{lllll}
\hline Variables & Coefficient & Std. Error & t-Statistic & Prob. \\
\hline EOI & 0.015498 & 0.053094 & 0.29189 & 0.7739 \\
C & 12.36059 & 1.928829 & 6.408339 & 0 \\
R-squared & 0.004987 & Mean dependent var & 12.92211 \\
Adjusted R-squared & -0.05354 & S.D. dependent var & 0.595563 \\
S.E. of regression & 0.611299 & Akaike info criterion & 1.952841 \\
Sum squared resid & 6.352678 & Schwarz criterion & 2.052255 \\
Log likelihood & -16.552 & F-statistic & 0.0852 \\
Durbin-Watson stat & 0.038802 & Prob(F-statistic) & 0.773903 \\
Included observations: 19 & & \\
\hline
\end{tabular}

Source: Estimated by the author based on Appendix-III and IV. 


\section{Impact on Industrial GDP}

By comparing the growth of industrial GDP in the pre-liberalization and postliberalization, there is positive impact of economic openness and industrial GDP in the pre-liberalization period but result is opposite in the post-liberalization period. Though there is positive impact of economic openness and industrial GDP in the total observed period.

Table 9: Regression between Industrial GDP and Economic Openness during $1974 / 75$ to $2009 / 10$

Dependent pendent Variable: lnGDPID

\begin{tabular}{lllll}
\hline Variables & Coefficient & Std. Error & t-Statistic & Prob. \\
\hline EOI & 0.169502 & 0.013664 & 12.40491 & 0 \\
C & 3.956243 & 0.410732 & 9.632166 & 0 \\
R-squared & 0.819035 & Mean dependent var & 8.860895 \\
Adjusted R-squared & 0.813713 & S.D. dependent var & 1.54648 \\
S.E. of regression & 0.667477 & Akaike info criterion & 2.083328 \\
Sum squared resid & 15.14786 & Schwarz criterion & 2.171302 \\
Log likelihood & -35.4999 & F-statistic & 153.8817 \\
Durbin-Watson stat & 0.397758 & Prob(F-statistic) & 0 \\
Included observations: 36 & & \\
\hline
\end{tabular}

Source: Estimated by the author based on Appendix-III and IV.

The relationship between economic openness and industrial GDP is positive during $1974 / 75$ to $2009 / 10$. The result of regression analysis shows that the effect of EOI is positive with coefficient $\mathrm{R}^{2}=0.81$ having significant at 1 percent critical value. This implies that the economic openness has positive impact on industrial GDP (Table 9).

Table10: Regression between Industrial GDP and Economic Openness in the Preliberalization Period (1974/75-1991/92)

\begin{tabular}{|c|c|c|c|c|}
\hline Variables & Coefficient & Std. Error & $\mathrm{t}$-Statistic & Prob. \\
\hline EOI & 0.246557 & 0.041816 & 5.896245 & 0 \\
\hline $\mathrm{C}$ & 2.308897 & 0.87551 & 2.637201 & 0.0187 \\
\hline R-squared & 0.698588 & \multicolumn{2}{|c|}{ Mean dependent var } & 7.432427 \\
\hline Adjusted R-squared & 0.678493 & \multicolumn{2}{|c|}{ S.D. dependent var } & 0.778004 \\
\hline S.E. of regression & 0.44114 & \multicolumn{2}{|c|}{ Akaike info criterion } & 1.311223 \\
\hline Sum squared resid & 2.919071 & \multicolumn{2}{|c|}{ Schwarz criterion } & 1.409248 \\
\hline Log likelihood & -9.1454 & \multicolumn{2}{|c|}{ F-statistic } & 34.7657 \\
\hline Durbin-Watson stat & 1.345155 & \multicolumn{2}{|c|}{ Prob(F-statistic) } & 0.000029 \\
\hline
\end{tabular}

Source: Estimated by the author based on Appendix-III and IV. 
Similarly the same result can be found during pre-liberalization period (Table10). However, during post liberalization period, the EOI $(b=0.01347)$ seems to be unrelated to industrial GDP because it is statistically insignificant. This seems to indicate that the economic openness is not an important factor in predicting industrial GDP (Table 11).

Table 11: Regression between Industrial GDP and Economic Openness in the Postliberalization Period (1991/92-2009/10)

Dependent Variable: lnGDPID

\begin{tabular}{lllll}
\hline Variables & Coefficient & Std. Error & t-Statistic & Prob. \\
\hline EOI & 0.013473 & 0.060572 & 0.222424 & 0.8266 \\
C & 9.650851 & 2.2005 & 4.385753 & 0.0004 \\
R-squared & 0.002902 & Mean dependent var & 10.139 \\
Adjusted R-squared & -0.05575 & S.D. dependent var & 0.678854 \\
S.E. of regression & 0.697521 & Akaike info criterion & 2.216731 \\
Sum squared resid & 8.271093 & Schwarz criterion & 2.316146 \\
Log likelihood & -19.0589 & F-statistic & 0.049472 \\
Durbin-Watson stat & 0.038578 & Prob(F-statistic) & 0.826635 \\
Included observations: 19 & & \\
\hline
\end{tabular}

Source: Estimated by the author based on Appendix-III and IV.

The process of industrialization was adversely affected during conflict and political instability period due to the deterioration in peace and security situation in the country. In addition to this, the industrial sector has faced problems like, energy shortage, lack of physical infrastructure, low utilization of the capacity, lack of proper business environment, weak basic infrastructure, problems in technology transfer and other causes leading to a decline in the production, lack of competitive capacity and a small domestic market.

\section{Impact on Investment}

To examine the influence of Economic Openness on investment, in this study natural log of investment (lnINVEST) has been regressed on economic openness index (EOI), using data of 1974/75 - 2009/10. The result shows that the overall model is significant with coefficient $R^{2}=0.82$ having significant at 1 percent critical value. This means that for each increase in economic openness implies the increase in investment (Table 12). 
Table 12: Regression between Investment and Economic Openness during 1974/75 to $2009 / 10$

Dependent Variable: InINVEST

\begin{tabular}{lllll}
\hline Variables & Coefficient & Std. Error & t-Statistic & Prob. \\
\hline EOI & 0.170005 & 0.013453 & 12.63697 & 0 \\
C & 3.052186 & 0.404387 & 7.547695 & 0 \\
R-squared & 0.824464 & Mean dependent var & 7.971389 \\
Adjusted R-squared & 0.819302 & S.D. dependent var & 1.545987 \\
S.E. of regression & 0.657178 & Akaike info criterion & 2.052228 \\
Sum squared resid & 14.68401 & Schwarz criterion & 2.140201 \\
Log likelihood & -34.9401 & F-statistic & 159.693 \\
Durbin-Watson stat & 0.273656 & Prob(F-statistic) & 0 \\
Included observations: 36 & & \\
\hline
\end{tabular}

Source: Estimated by the author based on Appendix-IV and V.

By comparing the growth of investment in the pre-liberalization (1974/75-1991/92) and post-liberalization (1991/92-2009/10), there is positive impact of economic openness on investment in the pre-liberalization period but the result is opposite in the postliberalization period. The statistically significant relationship with coefficient $R^{2}=0.79$ having significant at 1 percent critical value during 1974/75-1991/92), indicates that the economic openness has positive influence on investment (Table 13).

Table 13: Regression between Investment and Economic Openness in the Preliberalization Period (1974/75-1991/92)

Dependent Variable: InINVEST

\begin{tabular}{lllll}
\hline Variables & Coefficient & Std. Error & t-Statistic & Prob. \\
\hline EOI & 0.258921 & 0.033684 & 7.686779 & 0 \\
C & 1.169627 & 0.705239 & 1.658484 & 0.118 \\
R-squared & 0.797534 & Mean dependent var & 6.55 \\
Adjusted R-squared & 0.784036 & S.D. dependent var & 0.764747 \\
S.E. of regression & 0.355392 & Akaike info criterion & 0.878941 \\
Sum squared resid & 1.894554 & Schwarz criterion & 0.976966 \\
Log likelihood & -5.471 & F-statistic & 59.08657 \\
Durbin-Watson stat & 1.1859 & Prob(F-statistic) & 0.000001 \\
Included observations: 17 & & \\
\hline
\end{tabular}

Source: Estimated by the author based on Appendix-IV and V. 
But, in the post-liberalization period, the relationship is not significant because the critical value is 68 percent and coefficient $R^{2}=0.0098$. The economic openness has not influenced the investment in the post-liberalization period (Table 14). In sum, conclusion can be drawn that the economic openness has positive influence during $1974 / 75$ to $1991 / 92$ and $1974 / 75$ to $2009 / 10$, but there is virtually no influence during $1991 / 92$ to $2009 / 10$.

Table 14: Regression between Investment and Economic Openness in the Postliberalization Period (1991/92-2009/10)

Dependent Variable: lnINVEST

\begin{tabular}{|c|c|c|c|c|}
\hline Variables & Coefficient & Std. Error & $\mathrm{t}$-Statistic & Prob. \\
\hline EOI & 0.02618 & 0.063643 & 0.41135 & 0.686 \\
\hline $\mathrm{C}$ & 8.294603 & 2.312076 & 3.587513 & 0.0023 \\
\hline R-squared & 0.009855 & \multicolumn{2}{|c|}{ Mean dependent var } & 9.243158 \\
\hline Adjusted R-squared & -0.04839 & \multicolumn{2}{|c|}{ S.D. dependent var } & 0.715651 \\
\hline S.E. of regression & 0.732761 & \multicolumn{2}{|c|}{ Akaike info criterion } & 2.315306 \\
\hline Sum squared resid & 9.127956 & \multicolumn{2}{|c|}{ Schwarz criterion } & 2.414721 \\
\hline Log likelihood & -19.9954 & \multicolumn{2}{|c|}{ F-statistic } & 0.169209 \\
\hline Durbin-Watson stat & 0.052682 & \multicolumn{2}{|c|}{ Prob(F-statistic) } & 0.685955 \\
\hline \multicolumn{4}{|c|}{ Included observations: 19} & \\
\hline
\end{tabular}

Source: Estimated by the author based on Appendix-IV and V.

In order to find the impact of industrial policy on investment, this study regresses natural log of investment (InINVEST) on natural log of industrial policy dummy (IPDUM).

\section{Impact on Total Revenue}

The results of regression analysis show that that there is a significance positive relationship between economic openness and total revenue during 1974/75 to 2009/10. The results are statistically significant with R-squared 0.82 having significant at 1 percent critical value. The coefficient for economic Openness Index is 0.1681 ( $t=12.4949$, $\mathrm{p}<.001)$. This implies that for each additional increase in EOI, total revenue increases by 0.17 points. These results indicate that Economic Openness Index influence their overall performance in the total revenue (Table 15). 
Table 15: Regression between Total Revenue and Economic Openness during $1974 / 75$ to $2009 / 10$

\begin{tabular}{lllll} 
Dependent Variable: InTR & \multicolumn{5}{l}{} \\
\hline Variables & Coefficient & Std. Error & t-Statistic & Prob. \\
\hline EOI & 0.16814 & 0.013457 & 12.49491 & 0 \\
C & 4.381998 & 0.404496 & 10.83322 & 0 \\
R-squared & 0.821168 & Mean dependent var & 9.247222 \\
Adjusted R-squared & 0.815909 & S.D. dependent var & 1.532088 \\
S.E. of regression & 0.657356 & Akaike info criterion & 2.052771 \\
Sum squared resid & 14.69198 & Schwarz criterion & 2.140744 \\
Log likelihood & -34.9499 & F-statistic & 156.1229 \\
Durbin-Watson stat & 0.32387 & Prob(F-statistic) & 0 \\
Included observations: 36 & & &
\end{tabular}

Source: Estimated by the author based on Appendix-III and IV.

Using regression, the relationship has been analyzed between the natural log of total revenue (lnTR) and economic openness index (EOI). The result seems to be valid as all diagnostic parameters justify the relationship such as the regression coefficient is significant at 1 percent $t$-value with $R^{2}=0.79$. In sum, the result can be interpreted that there is significant impact of economic openness on the total revenue (Table 16).

Table 16: Regression between Total Revenue and Economic Openness in the Preliberalization Period (1974/75-1991/92)

\begin{tabular}{lllll} 
Dependent Variable: lnTR & \multicolumn{3}{l}{} \\
\hline Variable & Coefficient & Std. Error & t-Statistic & Prob. \\
\hline EOI & 0.246667 & 0.03268 & 7.547917 & 0 \\
C & 2.714852 & 0.684222 & 3.967792 & 0.0012 \\
R-squared & 0.791583 & Mean dependent var & 7.840588 \\
Adjusted R-squared & 0.777688 & S.D. dependent var & 0.731287 \\
S.E. of regression & 0.344801 & Akaike info criterion & 0.818434 \\
Sum squared resid & 1.78332 & Schwarz criterion & 0.91646 \\
Log likelihood & -4.95669 & F-statistic & 56.97106 \\
Durbin-Watson stat & 1.4125 & Prob(F-statistic) & 0.000002 \\
Included observations: 17 & & & \\
\hline
\end{tabular}

Source: Estimated by the author based on Appendix-III and IV. 
However, the relationship between EOI and total revenue during post-liberalization period (1991/92-2009/10), is not statistically significant with coefficient 0.013 having insignificant critical value 63 percent in the post-liberalization period. It indicates that Economic Openness Index (EOI) does not influence the total revenue (Table 17). It means, there is no impact of economic openness on the growth of revenue in Nepal.

Table 17: Regression between Total Revenue and Economic Openness in the Postliberalization Period (1991/92-2009/10)

Dependent Variable: $\operatorname{lnTR}$

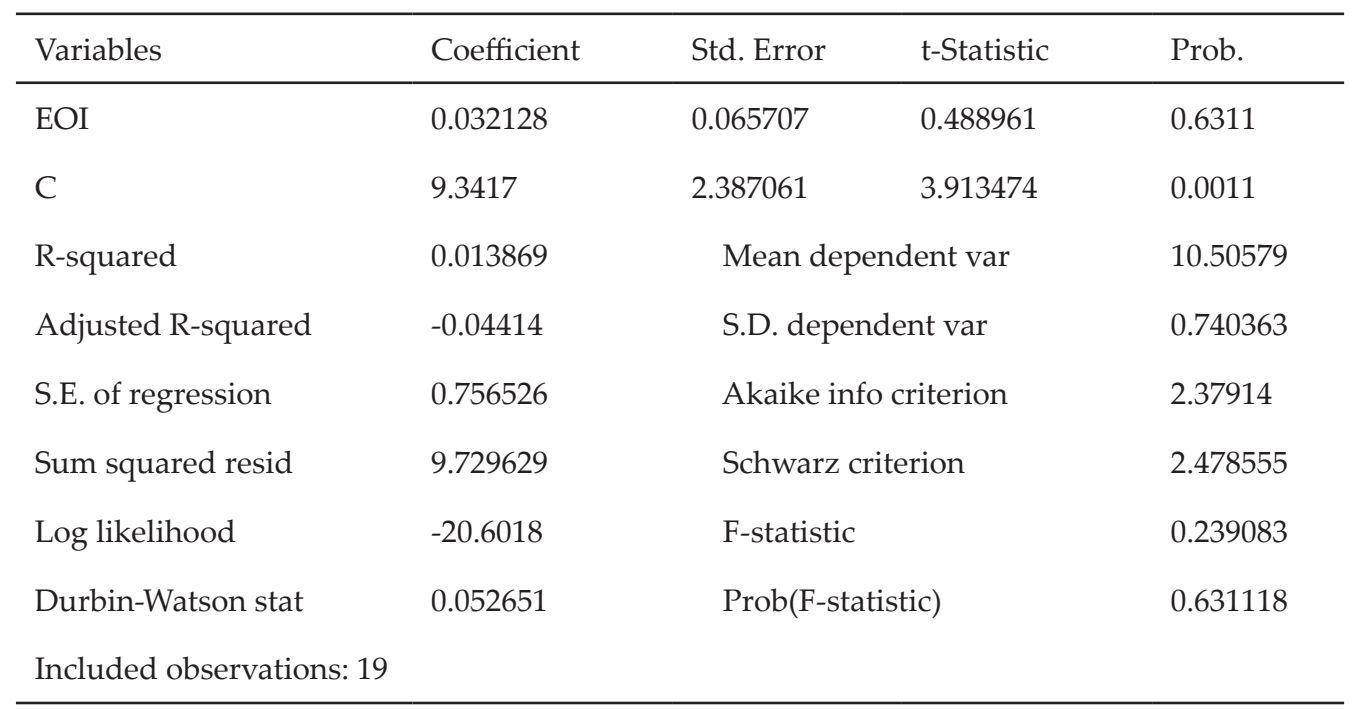

Source: Estimated by the author based on Appendix-III and IV

Similarly, there is significant positive relationship between total revenue and industrial policy dummy during the whole observed period (1974/75-2009/10). The relationship between these variables is statistically significant. The regression is poor fit $\left(R^{2}=0.2150\right)$, but overall model is significant $(p=0.0043)$. This implies that policy changes have influence on total revenue (Table 17).

\section{Impact on Trade Tax}

Regressing trade tax (TT) on economic openness index (EOI), positive relationship can be found during 1974/75-2009/10. 
Table 20: Regression between Trade Tax and Economic Openness during 1974/75 2009/10

Dependent Variable: $\operatorname{lnTT}$

\begin{tabular}{lllll}
\hline Variables & Coefficient & Std. Error & t-Statistic & Prob. \\
\hline EOI & 0.157458 & 0.011677 & 13.48426 & 0 \\
C & 3.587188 & 0.351007 & 10.21971 & 0 \\
R-squared & 0.842465 & Mean dependent var & 8.143333 \\
Adjusted R-squared & 0.837832 & S.D. dependent var & 1.416507 \\
S.E. of regression & 0.570429 & Akaike info criterion & 1.769097 \\
Sum squared resid & 11.06323 & Schwarz criterion & 1.85707 \\
Log likelihood & -29.8437 & F-statistic & 181.8252 \\
Durbin-Watson stat & 0.401381 & Prob(F-statistic) & 0 \\
Included observations: 36 & & & \\
\hline
\end{tabular}

Source: Estimated by the author based on Appendix-III and IV.

The result seems to be valid as all diagnostic parameters justify the relationship such as the regression coefficient is significant at $t$-value which is 1 percent $\left(R^{2}=0.8424\right.$, $\mathrm{p}=0.0000$ ). The result can be interpreted that there is significant impact of economic openness on trade tax in Nepal during the observed period (Table 20).

There is positive impact of economic openness on trade tax in the pre-liberalization period but result is opposite in the post-liberalization period. The pre-liberalization period covering 1974/75 to 1991/92, the impact of economic openness on trade tax is statistically significant $\left(\mathrm{R}^{2}=0.7518, \mathrm{p}=0.0000\right)$. This indicates that as economic openness increases, the trade tax in Nepal also increases (Table 21).

Table 21: Regression between Trade Tax and Economic Openness in the Preliberalization (1974/75-1991/92)

Dependent Variable: $\operatorname{lnTT}$

\begin{tabular}{lllll}
\hline Variables & Coefficient & Std. Error & t-Statistic & Prob. \\
\hline EOI & 0.234335 & 0.034759 & 6.741651 & 0 \\
C & 1.962878 & 0.727753 & 2.697175 & 0.0166 \\
R-squared & 0.75186 & Mean dependent var & 6.832353 \\
Adjusted R-squared & 0.735318 & S.D. dependent var & 0.712842 \\
S.E. of regression & 0.366738 & Akaike info criterion & 0.941792 \\
Sum squared resid & 2.01745 & Schwarz criterion & 1.039817 \\
Log likelihood & -6.00524 & F-statistic & 45.44985 \\
Durbin-Watson stat & 1.273898 & Prob(F-statistic) & 0.000007 \\
Included observations: 17 & & \\
\hline
\end{tabular}

Source: Estimated by the author based on Appendix-III and IV.

62 
But, the regression of post liberalization (1991/92-2009/10) is not statistically significant $\left(\mathrm{R}^{2}=0.0310, \mathrm{p}=0.4702\right)$ (Table 22). This finding indicates that economic openness does not influence trade tax.

Table 22: Regression between Trade Tax and Economic Openness in the Postliberalization (1991/92-2009/10)

Dependent Variable: $\operatorname{lnTT}$

\begin{tabular}{lllll}
\hline Variables & Coefficient & Std. Error & t-Statistic & Prob. \\
\hline EOI & 0.039754 & 0.053822 & 0.738617 & 0.4702 \\
C & 7.87593 & 1.955285 & 4.028021 & 0.0009 \\
R-squared & 0.031094 & Mean dependent var & 9.316316 \\
Adjusted R-squared & -0.0259 & S.D. dependent var & 0.611812 \\
S.E. of regression & 0.619684 & Akaike info criterion & 1.980087 \\
Sum squared resid & 6.528144 & Schwarz criterion & 2.079502 \\
Log likelihood & -16.8108 & F-statistic & 0.545556 \\
Durbin-Watson stat & 0.06957 & Prob(F-statistic) & 0.470215 \\
Included observations: 19 & & & \\
\hline
\end{tabular}

Source: Estimated by the author based on Appendix-III and IV.

While regressing trade tax (TT) on industrial dummy, statistically significant relationship can be found during the whole observed period (1974/75-2009/10). The regression is a good fit $\left(R^{2}=0.79\right)$, and overall model is significant $(p=0.0062)$. This shows that policy changes have positive impact on Trade tax in Nepal (Table 23).

Table 23: Regression between Total Revenue and Economic Openness in the Preliberalization Period (1974/75-1991/92)

\begin{tabular}{lllll} 
Dependent Variable: $\operatorname{lnTR}$ & \multicolumn{5}{l}{} \\
\hline Variables & Coefficient & Std. Error & t-Statistic & Prob. \\
\hline EOI & 0.246667 & 0.03268 & 7.547917 & 0 \\
C & 2.714852 & 0.684222 & 3.967792 & 0.0012 \\
R-squared & 0.791583 & Mean dependent var & 7.840588 \\
Adjusted R-squared & 0.777688 & S.D. dependent var & 0.731287 \\
S.E. of regression & 0.344801 & Akaike info criterion & 0.818434 \\
Sum squared resid & 1.78332 & Schwarz criterion & 0.91646 \\
Log likelihood & -4.95669 & F-statistic & 56.97106 \\
Durbin-Watson stat & 1.4125 & Prob(F-statistic) & 0.000002 \\
Included observations: 17 & & & \\
\hline
\end{tabular}

Source: Estimated by the author based on Appendix-III and IV. 


\section{Impact on Total Trade}

Despite its significant geographical constraints and policy and institutional weaknesses, Nepal has comparative advantage in a number of labor-intensive manufacturing and agricultural products. However, Nepal's trade performance over recent years has been highly variable, reflecting the formidable constraints to realizing this potential. Even with structural change in its merchandise exports, Nepal remains dependent on a relatively small basket of exports and a few destination markets. A significant share of its exports face dwindling world demand, making the continuing restructuring of its export basket urgent. With regard to trade policy, Nepal has significantly opened up trade in the past decades. Foreign trade is one of the most important determinants of Nepalese economy as it remains crucial to meet the domestic supply of goods and services on the one hand, and on the other, it provides a significant share of incomes as trade tax revenues.

Regression analysis shows significant positive relationship between economic openness and total trade during 1974/75 to 2009/10. The result indicates that the economic openness, the independent variable EOI $\left(b=0.184355, p=0.00, R^{2}=0.87\right)$ seems to be related to trade (Table 24).

Table 24: Regression between Total Trade and Economic Openness during 1974/75 to $2009 / 10$

Dependent Variable: lnTRADE

\begin{tabular}{lllll}
\hline Variables & Coefficient & Std. Error & t-Statistic & Prob. \\
\hline EOI & 0.184355 & 0.011961 & 15.41356 & 0 \\
C & 5.191696 & 0.359525 & 14.44045 & 0 \\
R-squared & 0.874806 & Mean dependent var & 10.52611 \\
Adjusted R-squared & 0.871124 & S.D. dependent var & 1.627526 \\
S.E. of regression & 0.584272 & Akaike info criterion & 1.817051 \\
Sum squared resid & 11.60669 & Schwarz criterion & 1.905025 \\
Log likelihood & -30.7069 & F-statistic & 237.5779 \\
Durbin-Watson stat & 0.366493 & Prob(F-statistic) & 0 \\
Included observations: 36 & & & \\
\hline
\end{tabular}

Source: Estimated by the author based on Appendix-III and IV.

This seems to indicate that the economic openness is an important factor in predicting trade. Similar relationship is found between economic openness (EOI) and total trade in the pre-liberalization period. The coefficient $b=0.262536, p=0.0000$ and $R^{2}=0.807$ indicate that there is considerable impact of economic openness on foreign trade (Table 25). 
Table 25: Regression between Total Trade and Economic Openness in the Preliberalization Period (1974/75-1991/92)

\begin{tabular}{lllll}
\multicolumn{5}{l}{ Dependent Variable: lnTRADE } \\
Variable & Coefficient & Std. Error & t-Statistic & Prob. \\
\hline EOI & 0.262536 & 0.033044 & 7.945004 & 0 \\
C & 3.52861 & 0.691846 & 5.100285 & 0.0001 \\
R-squared & 0.807995 & Mean dependent var & 8.984118 \\
Adjusted R-squared & 0.795195 & S.D. dependent var & 0.77039 \\
S.E. of regression & 0.348643 & Akaike info criterion & 0.840594 \\
Sum squared resid & 1.823279 & Schwarz criterion & 0.938619 \\
Log likelihood & -5.14505 & F-statistic & 63.12308 \\
Durbin-Watson stat & 1.290569 & Prob(F-statistic) & 0.000001 \\
Included observations: 17 & & &
\end{tabular}

Source: Estimated by the author based on Appendix-III and IV.

But, the result is opposite in the post-liberalization period. In post- liberalization period, the relationship between economic openness and trade is significant $(b=0.04246$, $\mathrm{p}=0.4361$ and $\mathrm{R}^{2}=0.036$ ). This indicates that the economic openness is unrelated to trade (Table 26).

Table 26: Regression between Total Trade and Economic Openness in the Postliberalization Period (1991/92-2009/10)

Dependent Variable: InTRADE

\begin{tabular}{lllll}
\hline Variables & Coefficient & Std. Error & t-Statistic & Prob. \\
\hline EOI & 0.042456 & 0.053233 & 0.797549 & 0.4361 \\
C & 10.36749 & 1.933899 & 5.360929 & 0.0001 \\
R-squared & 0.036067 & Mean dependent var & 11.90579 \\
Adjusted R-squared & -0.02064 & S.D. dependent var & 0.606679 \\
S.E. of regression & 0.612906 & Akaike info criterion & 1.95809 \\
Sum squared resid & 6.386115 & Schwarz criterion & 2.057505 \\
Log likelihood & -16.6019 & F-statistic & 0.636085 \\
Durbin-Watson stat & 0.039606 & Prob(F-statistic) & 0.436131 \\
Included observations: 19 & & & \\
\hline
\end{tabular}

Source: Estimated by the author based on Appendix-III and IV.

\section{Impact on Trade Balance}

Theoretically, economic liberalization is expected to help increase the export trade. The increase in export trade also helps to maintain trade balance in the country. In 
order to examine the relationship between economic openness and trade balance, this study performs regression analysis. This analysis conducts simple regression, where natural $\log$ of trade balance (lnTBL) has been regressed on economic openness index (EOI). The results are statistically significant $\left(\mathrm{R}^{2}=0.8405, \mathrm{p}=0.0000\right)$, indicating that EOI accounted for 84 percent of the variance in trade balance. The regression coefficient (b) is 0.1904 ( $\mathrm{t}=13.3899, \mathrm{p}<.001)$. This means that for any effort to increase in economic openness, the trade balance increases. These results indicate that economic openness influences the trade balance (Table 27).

Table 27: Regression between Trade Balance and Economic Openness during 1974/75 to $2009 / 10$

Dependent Variable: $\ln$ TBAL

\begin{tabular}{lllll}
\hline Variables & Coefficient & Std. Error & t-Statistic & Prob. \\
\hline EOI & 0.190478 & 0.014225 & 13.38995 & 0 \\
C & 4.265911 & 0.427605 & 9.976286 & 0 \\
R-squared & 0.840593 & Mean dependent var & 9.7775 \\
Adjusted R-squared & 0.835905 & S.D. dependent var & 1.715461 \\
S.E. of regression & 0.694911 & Akaike info criterion & 2.163886 \\
Sum squared resid & 16.41863 & Schwarz criterion & 2.251859 \\
Log likelihood & -36.95 & F-statistic & 179.2907 \\
Durbin-Watson stat & 0.336871 & Prob(F-statistic) & 0 \\
Included observations: 36 & & & \\
\hline
\end{tabular}

Source: Estimated by the author based on Appendix-III and IV.

By comparing the growth of trade balance in the pre-liberalization and postliberalization, there is positive impact of economic openness and trade balance in the pre-liberalization period but result is opposite in the post-liberalization period. Though there is positive impact of economic openness and trade balance in the total period. There is a significant positive relationship between economic openness and trade balance in the pre-liberalization period (1974/75-2009/10). The result seems to be valid as all diagnostic parameters justify the relationship such as the regression coefficient is significant at 1 percent $t$-value with $R^{2}=0.80$. In sum, the result can be interpreted that there is significant impact of economic openness on trade balance (Table 28). 
Table 28: Regression between Trade Balance and Economic Openness in the Preliberalization (1974/75-1991/92)

\begin{tabular}{lllll}
\multicolumn{1}{l}{ Dependent Variable: lnTBAL } & & \\
\hline Variable & Coefficient & Std. Error & t-Statistic & Prob. \\
\hline EOI & 0.336789 & 0.042248 & 7.971653 & 0 \\
C & 1.220927 & 0.884553 & 1.380276 & 0.1877 \\
R-squared & 0.809032 & Mean dependent var & 8.219412 \\
Adjusted R-squared & 0.796301 & S.D. dependent var & 0.987645 \\
S.E. of regression & 0.445754 & Akaike info criterion & 1.332033 \\
Sum squared resid & 2.980453 & Schwarz criterion & 1.430058 \\
Log likelihood & -9.32228 & F-statistic & 63.54725 \\
Durbin-Watson stat & 1.564786 & Prob(F-statistic) & 0.000001 \\
Included observations: 17 & & &
\end{tabular}

Source: Estimated by the author based on Appendix-III and IV.

In the post-liberalization period (1991/92-2009/10), the relationship between trade balance and economic openness is not significant $\left(R^{2}=0.0492, F=0.8800, p=0.3613\right)$. The result seems to be invalid as all diagnostic parameters justify the relationship such as the regression coefficient is insignificant at $t$-value which is above 5 percent. This means that there is no influence of economic openness on trade balance (Table 29).

Table 29: Regression between Trade Balance and Economic Openness in the Postliberalization (1991/92-2009/10)

Dependent Variable: $\operatorname{lnTBAL}$

\begin{tabular}{lllll}
\hline Variables & Coefficient & Std. Error & t-Statistic & Prob. \\
\hline EOI & 0.058431 & 0.062287 & 0.9381 & 0.3613 \\
C & 9.054461 & 2.262804 & 4.001434 & 0.0009 \\
R-squared & 0.049219 & Mean dependent var & 11.17158 \\
Adjusted R-squared & -0.00671 & S.D. dependent var & 0.714751 \\
S.E. of regression & 0.717145 & Akaike info criterion & 2.272224 \\
Sum squared resid & 8.743055 & Schwarz criterion & 2.371639 \\
Log likelihood & -19.5861 & F-statistic & 0.880032 \\
Durbin-Watson stat & 0.070903 & Prob(F-statistic) & 0.361331 \\
Included observations: 19 & & & \\
\hline
\end{tabular}

Source: Estimated by the author based on Appendix-III and IV. 


\section{SUMMARY OF THE FINDINGS}

This study has analyzed the impacts of industrial policies on the industrialization of the country by assessing the relationships between different macroeconomic variables such as GDP, industrial GDP, investment, export and import trade, trade balance, total revenue, trade tax, number of registration of industries, employment as dependent variables and economic openness proxied by Economic Openness Index (EOI) as independent variable. Followings are the major findings of this study:

(i) The result shows that there is a significant positive relationship between economic openness and GDP during 1974/75-2009/10, indicating increase in economic openness has positive influence on GDP. By comparing the growth of GDP in the pre-liberalization (1974/75- 1991/92) and post-liberalization (1991/92 - 2009/10) period, there is positive impact of economic openness and GDP in the pre-liberalization period but result is opposite in the post-liberalization period.

(ii) The relationship between economic openness and industrial GDP is positive during 1974/75 to 2009/10. There is also positive impact of economic openness and industrial GDP in the pre-liberalization period but result is opposite in the post-liberalization period.

(iii) This study reveals that the economic openness has influence on the investment during 1974/75 - 2009/10. By comparing the growth of investment in the preliberalization (1974/75-1991/92) and post-liberalization (1991/92-2009/10), there is positive impact of economic openness on the investment in the pre-liberalization period but the result is opposite in the post-liberalization period. In sum, conclusion can be drawn that the economic openness has positive influence during $1974 / 75$ to $1991 / 92$ and $1974 / 75$ to $2009 / 10$, but there is virtually no influence during 1991/92 to 2009/10.

(iv) Regression analysis shows the significant positive relationship between economic openness and total trade during 1974/75 to 2009/10. This seems to indicate that the economic openness is an important factor in predicting trade. Similar relationship is found between economic openness index (EOI) and total trade (TRADE) in the pre-liberalization period. But, the result is opposite in the post-liberalization period. In post liberalization period, the relationship between economic openness and trade is insignificant. This indicates that the economic openness is unrelated to trade.

(v) There is a significant positive relationship between economic openness and trade balance during the period (1974/75-2009/10). Similarly, this analysis reveals that economic openness has positive impact on the trade balance during 1974/751991/92. These results indicate that economic openness influences the trade 
balance. But, the results shows that the relationship between trade balance and economic openness is not significant, meaning there is no influence of economic openness on trade balance during the post-liberalization period.

(vi) There is a significant positive relationship between economic openness and total revenue during 1974/75 to 2009/10 and pre-liberalization period. This means that Economic Openness influences their overall performance in total revenue. However, the relationship between EOI and total revenue during postliberalization period (1991/92-2009/10) is not statistically significant, indicating that Economic Openness Index (EOI) does not influence the total revenue.

(vii) A positive relationship can be found between trade tax and economic openness during 1974/75-2009/10. This means that there is significant impact of economic openness on trade revenue (customs) in Nepal during the observed period whereas the relationship in the pre-liberalization period is positive and postliberalization period is negative.

\section{CONCLUSIONS AND POLICY RECOMMENDATIONS}

Nepal practiced inward looking protectionist strategies before 1985 under which domestic industries were treated as 'infant industries' and were protected from foreign competition by high tariff and quota restrictions. The government was directly involved in the economy and provided essential products and services. But, this policy did not produce expected results. Nepal introduced market orientation policies in the mid 1980s and embarked on intensive economic liberalization in the early 1990s. At that time, Nepal was considered to be one of the most liberalized countries in the South Asian region. The industrial, trade and investment related policies were highly liberal. In the initial phase of liberalization, trade and investment increased substantially. However, that could not be sustained for long. The growth performance was poor in recent years, with low industrial growth, sluggish exports and almost stagnating investment.

This study finds that there is a significant positive relationship between economic openness and total GDP, industrial GDP, investment, trade, trade balance and FDI during 1974/75-2009/10, which indicates that increase economic openness has positive influence on these variables. When we assess the impact in pre (1974/75-1991/92) and post (1991/92-2009/10) liberalization period, the impact of openness on total GDP, industrial GDP, investment, trade, trade balance and FDI is positive during preliberalization period and opposite in post liberalization period. On the other hand, the impact is not uniform in different industries. 
The result of liberalization after 1990 is unexpected. The liberalization policies had been adopted with the hope of speeding up economic growth by accelerating the industrialization in the country. These policies then brought hopeful environment for industrial development in the country, though the results are not satisfactory. Both trade and investment grew rapidly in the aftermath of trade liberalization. However, the momentum of growth could not be maintained for long. At the same time, volatility in trade and investment circumscribed the scope for driving a higher economic growth rate in the longer term. The decline in export competitiveness as a result of high transaction costs has made the problem even more pervasive while the decline in labour productivity and the business environment has had adverse effects on FDI.

This study offers the following policy recommendations:

(i) Industrial policy in developing countries like Nepal should be specific rather than broad-based. One implication of this result is that deregulation is likely to be more successful in a relatively open economy than in a more closed economy.

(ii) There is need to adapt industrial policy to the changing regional and global environment, as par with at least the industrial policy of SAARC, BIMSTEC member countries. Policies should be in consistent with WTO provisions.

(iii) The government should focus on entrepreneurial development. This requires policy push in the initial stage of industrialization. Timely availability of finance at reasonable cost, suitable physical infrastructure, availability of technology for producing products for which demand exists and availability of market are essential for entrepreneurship development.

(iv) In order to have a positive impact of industrial policies on economic growth, reduction, employment, trade balance, etc., the industrial policy should promote industrial development in the rural areas.

(v) Industrial policies should aim at linkage creation, development of microenterprises and support to cottage industries may be directed more at employment generation and poverty alleviation.

(vi) There should be tripartite agreement between government, employers and workers to solve hire and fire complication. There should be political commitment to keep industrial peace zone.

(vii) Labour laws should make labour friendly to encourage the workers. Licensing provisions should make easy and transparent. Unnecessary strike and disturbances should be checked through the strict laws. 


\section{Appendices}

Annex-I: Number of Registration of Industries, Total Project Cost, Fixed Cost and Employment from 1974/75 -2009/10

\begin{tabular}{|c|c|c|c|c|}
\hline FY & No. of Industries & Total Project Cost & Total Fixed Cost & Employment \\
\hline $1974 / 75$ & 4 & 479.12 & 460.06 & 250 \\
\hline $1975 / 76$ & 6 & 564.12 & 522.69 & 784 \\
\hline $1976 / 77$ & 8 & 904.68 & 819.44 & 1271 \\
\hline $1977 / 78$ & 10 & 974.68 & 973.84 & 1463 \\
\hline $1978 / 79$ & 11 & 1086.38 & 1033.04 & 1628 \\
\hline $1979 / 80$ & 12 & 1181.38 & 1116.24 & 2642 \\
\hline $1980 / 81$ & 17 & 1919.62 & 1733.62 & 5202 \\
\hline $1981 / 82$ & 18 & 2008.63 & 1794.05 & 5289 \\
\hline $1982 / 83$ & 21 & 2118.63 & 1881.69 & 6515 \\
\hline $1983 / 84$ & 23 & 2163.15 & 1881.69 & 6515 \\
\hline $1984 / 85$ & 28 & 2919.18 & 2528.53 & 7037 \\
\hline $1985 / 86$ & 33 & 3120.50 & 2693.9 & 7990 \\
\hline $1986 / 87$ & 39 & 4058.33 & 3436.7 & 9275 \\
\hline $1987 / 88$ & 40 & 4103.34 & 3468.65 & 9346 \\
\hline $1988 / 89$ & 42 & 4168.76 & 3497.81 & 9567 \\
\hline $1989 / 90$ & 44 & 4200.19 & 3564.36 & 9821 \\
\hline 1990/91 & 136 & 5881.48 & 4676.1 & 15619 \\
\hline $1991 / 92$ & 437 & 7510.54 & 4676.89 & 38085 \\
\hline $1992 / 93$ & 606 & 10541.97 & 6667.44 & 89351 \\
\hline $1993 / 94$ & 147 & 18347.67 & 16483.59 & 20937 \\
\hline $1994 / 95$ & 213 & 17543.31 & 12892.73 & 21339 \\
\hline $1995 / 96$ & 374 & 20022.27 & 16733.04 & 34571 \\
\hline 1996/97 & 242 & 14032.46 & 10977.43 & 23745 \\
\hline $1997 / 98$ & 112 & 10531.68 & 8689.83 & 10136 \\
\hline $1998 / 99$ & 110 & 12546.5 & 9416.02 & 8882 \\
\hline 1999/00 & 158 & 25908.36 & 21368.9 & 15188 \\
\hline $2000 / 01$ & 145 & 10766.61 & 8064.46 & 9165 \\
\hline $2001 / 02$ & 139 & 22661.64 & 18747.48 & 11741 \\
\hline $2002 / 03$ & 109 & 13203.46 & 8666.02 & 12877 \\
\hline $2003 / 04$ & 147 & 13290.41 & 10292.43 & 11687 \\
\hline $2004 / 05$ & 107 & 18003.13 & 13758.76 & 8490 \\
\hline $2005 / 06$ & 120 & 9527.85 & 7105.84 & 10398 \\
\hline $2006 / 07$ & 177 & 8123.68 & 5973.02 & 9232 \\
\hline 2007/08 & 227 & 20126.36 & 15509.56 & 12844 \\
\hline 2008/09 & 302 & 26961.36 & 22526.92 & 20359 \\
\hline $2009 / 10$ & 258 & 39245.35 & 34352.81 & 14510 \\
\hline $2010 / 11$ & 242 & 90415.58 & 77913.17 & 13727 \\
\hline
\end{tabular}

Source:Department of Industry, Government of Nepal(2006 and 2012);Ministry of Finance(various years).Economic Survey(several issues). 
Annex-II: Natural Log of No. of Industries Registration, Total Project, Total Fixed Cost and Employment (1974/75-2009/10)

\begin{tabular}{|c|c|c|c|c|c|c|c|}
\hline FY & $\begin{array}{l}\text { No. of } \\
\text { Industries }\end{array}$ & $\begin{array}{l}\text { Total } \\
\text { Cost }\end{array}$ & Project & $\begin{array}{l}\text { Total } \\
\text { Cost }\end{array}$ & Fixed & Employment & EOI \\
\hline $1974 / 75$ & 1.39 & 6.17 & & 6.13 & & 5.52 & 16.29 \\
\hline $1975 / 76$ & 1.79 & 6.34 & & 6.26 & & 6.66 & 18.21 \\
\hline 1976/77 & 2.08 & 6.81 & & 6.71 & & 7.15 & 18.36 \\
\hline $1977 / 78$ & 2.30 & 6.88 & & 6.88 & & 7.29 & 17.82 \\
\hline $1978 / 79$ & 2.40 & 6.99 & & 6.94 & & 7.40 & 16.00 \\
\hline $1979 / 80$ & 2.48 & 7.07 & & 7.02 & & 7.88 & 19.83 \\
\hline $1980 / 81$ & 2.83 & 7.56 & & 7.46 & & 8.56 & 22.11 \\
\hline $1981 / 82$ & 2.89 & 7.61 & & 7.49 & & 8.57 & 20.72 \\
\hline $1982 / 83$ & 3.04 & 7.66 & & 7.54 & & 8.78 & 22.02 \\
\hline $1983 / 84$ & 3.14 & 7.68 & & 7.54 & & 8.78 & 20.92 \\
\hline $1984 / 85$ & 3.33 & 7.98 & & 7.84 & & 8.86 & 22.50 \\
\hline $1985 / 86$ & 3.50 & 8.05 & & 7.90 & & 8.99 & 22.28 \\
\hline $1986 / 87$ & 3.66 & 8.31 & & 8.14 & & 9.14 & 21.76 \\
\hline $1987 / 88$ & 3.69 & 8.32 & & 8.15 & & 9.14 & 23.38 \\
\hline $1988 / 89$ & 3.74 & 8.34 & & 8.16 & & 9.17 & 22.92 \\
\hline $1989 / 90$ & 3.78 & 8.34 & & 8.18 & & 9.19 & 22.71 \\
\hline $1990 / 91$ & 4.91 & 8.68 & & 8.45 & & 9.66 & 25.43 \\
\hline $1991 / 92$ & 6.08 & 8.92 & & 8.45 & & 10.55 & 30.54 \\
\hline $1992 / 93$ & 6.41 & 9.26 & & 8.80 & & 11.40 & 32.93 \\
\hline $1993 / 94$ & 4.99 & 9.82 & & 9.71 & & 9.95 & 35.56 \\
\hline $1994 / 95$ & 5.36 & 9.77 & & 9.46 & & 9.97 & 37.10 \\
\hline $1995 / 96$ & 5.92 & 9.90 & & 9.73 & & 10.45 & 37.90 \\
\hline $1996 / 97$ & 5.49 & 9.55 & & 9.30 & & 10.08 & 41.42 \\
\hline $1997 / 98$ & 4.72 & 9.26 & & 9.07 & & 9.22 & 38.73 \\
\hline $1998 / 99$ & 4.70 & 9.44 & & 9.15 & & 9.09 & 36.02 \\
\hline $1999 / 00$ & 5.06 & 10.16 & & 9.97 & & 9.63 & 41.72 \\
\hline $2000 / 01$ & 4.98 & 9.28 & & 9.00 & & 9.12 & 38.81 \\
\hline 2001/02 & 4.93 & 10.03 & & 9.84 & & 9.37 & 33.59 \\
\hline $2002 / 03$ & 4.69 & 9.49 & & 9.07 & & 9.46 & 35.41 \\
\hline $2003 / 04$ & 4.99 & 9.49 & & 9.24 & & 9.37 & 35.43 \\
\hline $2004 / 05$ & 4.67 & 9.80 & & 9.53 & & 9.05 & 35.32 \\
\hline $2005 / 06$ & 4.79 & 9.16 & & 8.87 & & 9.25 & 35.78 \\
\hline 2006/07 & 5.18 & 9.00 & & 8.70 & & 9.13 & 34.91 \\
\hline 2007/08 & 5.42 & 9.91 & & 9.65 & & 9.46 & 34.48 \\
\hline $2008 / 09$ & 5.71 & 10.20 & & 10.02 & & 9.92 & 35.64 \\
\hline $2009 / 10$ & 5.55 & 10.58 & & 10.44 & & 9.58 & 37.13 \\
\hline
\end{tabular}

Source: Author's computation from the publications of Department of Industry, Government of Nepal, and Ministry of Finance, Economic Survey (several issues). 
Annex-III: Total Volume of Trade, Total Import and Export Trade, Trade Tax, Total Revenue, Trade Balance, Industrial GDP and GDP (GDP at Current Price)

(Rs. in millions except GDP Deflator)

\begin{tabular}{|c|c|c|c|c|c|c|c|c|}
\hline \multirow{2}{*}{$\begin{array}{l}\text { Fiscal } \\
\text { Year } \\
\text { a }\end{array}$} & \multicolumn{4}{|c|}{ Trade Volume } & \multicolumn{2}{|l|}{ Revenue } & \multicolumn{2}{|l|}{ GDP } \\
\hline & $\begin{array}{l}\text { Imports } \\
b\end{array}$ & $\begin{array}{l}\text { Export } \\
\text { C }\end{array}$ & $\begin{array}{l}\text { Total } \\
\mathrm{d}=\mathrm{b}+\mathrm{c}\end{array}$ & $\begin{array}{l}\text { T. Balance } \\
\mathrm{c}-\mathrm{b}\end{array}$ & $\begin{array}{l}\text { Trade }^{1} \\
i=e+f+g+h\end{array}$ & $\begin{array}{l}\text { Total } \\
\mathrm{k}\end{array}$ & $\begin{array}{l}\text { at } \mathrm{cp} \\
1\end{array}$ & $\begin{array}{l}\text { Industrial } \\
\mathrm{n}\end{array}$ \\
\hline $1974 / 75$ & 1814.6 & 889.6 & 2704.2 & -925.0 & 328.522 & 841.776 & 16601.00 & 516.60 \\
\hline $1975 / 76$ & 1981.7 & 1185.8 & 3167.5 & -795.9 & 358.496 & 910.859 & 17394.00 & 589.90 \\
\hline $1976 / 77$ & 2008.0 & 1164.7 & 3172.7 & -843.3 & 386.193 & 1100.058 & 17280.30 & 689.10 \\
\hline $1977 / 78$ & 2469.6 & 1046.2 & 3515.8 & -1423.4 & 458.780 & 1243.795 & 19727.00 & 811.10 \\
\hline $1978 / 79$ & 2884.7 & 1296.8 & 4181.5 & -1587.9 & 626.714 & 1476.834 & 26128.00 & 1276.30 \\
\hline $1979 / 80$ & 3480.1 & 1150.5 & 4630.6 & -2329.6 & 608.013 & 1528.719 & 23351.00 & 983.10 \\
\hline $1980 / 81$ & 4428.2 & 1608.7 & 6036.9 & -2819.5 & 815.838 & 2035.724 & 27307.00 & 1002.00 \\
\hline $1981 / 82$ & 4930.3 & 1491.5 & 6421.8 & -3438.8 & 825.144 & 2211.365 & 30988.00 & 1327.30 \\
\hline $1982 / 83$ & 6314.0 & 1132.0 & 7446.0 & -5182.0 & 760.915 & 2421.143 & 33821.00 & 1473.90 \\
\hline $1983 / 84$ & 6514.3 & 1703.9 & 8218.2 & -4810.4 & 825.868 & 2736.978 & 39290.00 & 1672.00 \\
\hline $1984 / 85$ & 7742.1 & 2740.6 & 10482.7 & -5001.5 & 1064.382 & 3150.878 & 46587.03 & 2382.60 \\
\hline $1985 / 86$ & 9341.2 & 3078.1 & 12419.3 & -6263.1 & 1231.104 & 3659.467 & 55734.31 & 2859.80 \\
\hline $1986 / 87$ & 10905.2 & 2991.4 & 13896.6 & -7913.8 & 1505.700 & 4372.397 & 63864.50 & 3324.10 \\
\hline $1987 / 88$ & 13869.6 & 4114.5 & 17984.1 & -9755.1 & 2214.702 & 5754.405 & 76906.12 & 3641.50 \\
\hline $1988 / 89$ & 16263.7 & 4195.3 & 20459.0 & -12068.4 & 2289.921 & 6287.264 & 89269.62 & 4325.90 \\
\hline $1989 / 90$ & 18324.9 & 5156.2 & 23481.1 & -13168.7 & 2684.873 & 7283.942 & 103415.83 & 4923.20 \\
\hline $1990 / 91$ & 23226.5 & 7387.5 & 30614.0 & -15839.0 & 3044.282 & 8176.337 & 120370.27 & 6075.90 \\
\hline $1991 / 92$ & 31940.0 & 13706.5 & 45646.5 & -18233.5 & 3358.888 & 9875.568 & 149487.14 & 7977.70 \\
\hline $1992 / 93$ & 39205.6 & 17266.5 & 56472.1 & -21939.1 & 3944.986 & 11662.516 & 171473.89 & 9526.00 \\
\hline 1993/94 & 51570.8 & 19293.4 & 70864.2 & -32277.4 & 5255.042 & 15371.459 & 199272.00 & 11100.70 \\
\hline $1994 / 95$ & 63679.5 & 17639.2 & 81318.7 & -46040.3 & 7018.112 & 19660.072 & 219175.00 & 12440.50 \\
\hline $1995 / 96$ & 74454.5 & 19881.1 & 94335.6 & -54573.4 & 7327.364 & 21667.967 & 248913.00 & 14249.20 \\
\hline 1996/97 & 93553.4 & 22636.5 & 116189.9 & -70916.9 & 8309.119 & 24424.253 & 280513.00 & 16078.50 \\
\hline $1997 / 98$ & 89002.0 & 27513.5 & 116515.5 & -61488.5 & 8502.234 & 25939.818 & 300845.00 & 17730.30 \\
\hline $1998 / 99$ & 87525.3 & 35676.3 & 123201.6 & -51849.0 & 9517.674 & 28752.935 & 342036.00 & 19758.70 \\
\hline 1999/00 & 108504.9 & 49822.7 & 158327.6 & -58682.2 & 10813.304 & 33152.181 & 379488.00 & 22112.00 \\
\hline $2000 / 01$ & 115687.2 & 55654.1 & 171341.3 & -60033.1 & 12552.104 & 38865.002 & 441519.01 & 28589.40 \\
\hline $2001 / 02$ & 107388.9 & 46944.8 & 154333.7 & -60444.1 & 12658.738 & 39330.588 & 459442.81 & 29335.30 \\
\hline $2002 / 03$ & 124352.1 & 49930.6 & 174282.7 & -74421.5 & 14236.433 & 42586.935 & 492231.28 & 31942.90 \\
\hline $2003 / 04$ & 136277.1 & 53910.7 & 190187.8 & -82366.4 & 15554.775 & 48173.000 & 536748.88 & 35062.40 \\
\hline 2004/05 & 149473.6 & 58705.7 & 208179.3 & -90767.9 & 15701.599 & 54104.700 & 589411.55 & 39004.40 \\
\hline $2005 / 06$ & 173780.3 & 60234.1 & 234014.4 & -113546.2 & 15344.000 & 57430.400 & 654084.00 & 44238.00 \\
\hline $2006 / 07$ & 194694.6 & 59383.1 & 254077.7 & -135311.5 & 16707.600 & 71126.700 & 727827.00 & 50100.40 \\
\hline $2007 / 08$ & 221937.7 & 59266.5 & 281204.2 & -162671.2 & 21062.500 & 85155.500 & 815658.00 & 56846.70 \\
\hline 2008/09 & 284469.6 & 67697.5 & 352167.1 & -216772.1 & 26792.900 & 117051.90 & 988053.00 & 67850.00 \\
\hline 2009/10 & 374335.2 & 60824.0 & 435159.2 & -313511.2 & 35150.800 & 156294.90 & 1171905.00 & 78881.10 \\
\hline
\end{tabular}

Source: Ministry of Finance, Government of Nepal (various years).Economic Survey (several issues) 
Annex-IV: Natural Log of Import Trade, Export Trade, Total Trade, GDP, Industrial GDP, Trade Tax, Total Revenue with Economic Openness Index from 1974/752009/10

\begin{tabular}{|c|c|c|c|c|c|c|c|c|c|}
\hline Fiscal Year & lnmin & $\ln x i n$ & lntrade & lngdpid & lngdp & lninvest & EOI & $\ln t t$ & lntr \\
\hline $1974 / 75$ & 7.30 & 6.62 & 7.90 & 6.25 & 9.72 & 5.48 & 16.29 & 5.79 & 6.74 \\
\hline $1975 / 76$ & 7.11 & 6.80 & 8.06 & 6.38 & 9.76 & 5.57 & 18.21 & 5.88 & 6.81 \\
\hline $1976 / 77$ & 7.20 & 6.66 & 8.06 & 6.54 & 9.76 & 5.62 & 18.36 & 5.96 & 7.00 \\
\hline 1977/78 & 7.34 & 6.21 & 8.17 & 6.70 & 9.89 & 5.86 & 17.82 & 6.13 & 7.13 \\
\hline 1978/79 & 7.37 & 6.48 & 8.34 & 7.15 & 10.17 & 5.86 & 16.00 & 6.44 & 7.30 \\
\hline $1979 / 80$ & 7.49 & 6.26 & 8.44 & 6.89 & 10.06 & 6.06 & 19.83 & 6.41 & 7.33 \\
\hline $1980 / 81$ & 7.69 & 6.90 & 8.71 & 6.91 & 10.21 & 6.18 & 22.11 & 6.70 & 7.62 \\
\hline $1981 / 82$ & 7.73 & 6.90 & 8.77 & 7.19 & 10.34 & 6.28 & 20.72 & 6.72 & 7.70 \\
\hline $1982 / 83$ & 7.82 & 6.74 & 8.92 & 7.30 & 10.43 & 6.50 & 22.02 & 6.63 & 7.79 \\
\hline $1983 / 84$ & 8.03 & 7.06 & 9.01 & 7.42 & 10.58 & 6.60 & 20.92 & 6.72 & 7.91 \\
\hline $1984 / 85$ & 8.27 & 7.38 & 9.26 & 7.78 & 10.75 & 6.93 & 22.50 & 6.97 & 8.06 \\
\hline 1985/86 & 8.29 & 7.33 & 9.43 & 7.96 & 10.93 & 6.97 & 22.28 & 7.12 & 8.21 \\
\hline $1986 / 87$ & 8.36 & 7.19 & 9.54 & 8.11 & 11.06 & 7.16 & 21.76 & 7.32 & 8.38 \\
\hline 1987/88 & 8.43 & 7.36 & 9.80 & 8.20 & 11.25 & 7.33 & 23.38 & 7.70 & 8.66 \\
\hline $1988 / 89$ & 8.35 & 6.94 & 9.93 & 8.37 & 11.40 & 7.57 & 22.92 & 7.74 & 8.75 \\
\hline 1989/90 & 8.45 & 6.40 & 10.06 & 8.50 & 11.55 & 7.55 & 22.71 & 7.90 & 8.89 \\
\hline 1990/91 & 8.90 & 7.35 & 10.33 & 8.71 & 11.70 & 7.83 & 25.43 & 8.02 & 9.01 \\
\hline $1991 / 92$ & 9.33 & 7.28 & 10.73 & 8.98 & 11.91 & 8.06 & 30.54 & 8.12 & 9.20 \\
\hline 1992/93 & 9.44 & 7.39 & 10.94 & 9.16 & 12.05 & 8.29 & 32.93 & 8.28 & 9.36 \\
\hline 1993/94 & 9.74 & 7.79 & 11.17 & 9.31 & 12.20 & 8.40 & 35.56 & 8.57 & 9.64 \\
\hline 1994/95 & 9.88 & 8.05 & 11.31 & 9.43 & 12.30 & 8.62 & 37.10 & 8.86 & 9.89 \\
\hline $1995 / 96$ & 10.10 & 8.21 & 11.45 & 9.56 & 12.42 & 8.82 & 37.90 & 8.90 & 9.98 \\
\hline 1996/97 & 10.12 & 8.56 & 11.66 & 9.69 & 12.54 & 8.87 & 41.42 & 9.03 & 10.10 \\
\hline $1997 / 98$ & 10.22 & 9.08 & 11.67 & 9.78 & 12.61 & 8.92 & 38.73 & 9.05 & 10.16 \\
\hline 1998/99 & 10.38 & 9.44 & 11.72 & 9.89 & 12.74 & 8.85 & 36.02 & 9.16 & 10.27 \\
\hline 1999/00 & 10.59 & 9.96 & 11.97 & 10.00 & 12.85 & 9.13 & 41.72 & 9.29 & 10.41 \\
\hline $2000 / 01$ & 10.72 & 10.17 & 12.05 & 10.26 & 13.00 & 9.20 & 38.81 & 9.44 & 10.57 \\
\hline $2001 / 02$ & 10.94 & 10.24 & 11.95 & 10.29 & 13.04 & 9.14 & 33.59 & 9.45 & 10.58 \\
\hline $2002 / 03$ & 11.17 & 10.18 & 12.07 & 10.37 & 13.11 & 9.26 & 35.41 & 9.56 & 10.66 \\
\hline $2003 / 04$ & 11.27 & 10.33 & 12.16 & 10.46 & 13.19 & 9.49 & 35.43 & 9.65 & 10.78 \\
\hline $2004 / 05$ & 11.39 & 10.57 & 12.25 & 10.57 & 13.29 & 9.65 & 35.32 & 9.66 & 10.90 \\
\hline $2005 / 06$ & 11.58 & 10.61 & 12.36 & 10.70 & 13.39 & 9.77 & 35.78 & 9.64 & 10.96 \\
\hline $2006 / 07$ & 11.66 & 10.64 & 12.45 & 10.82 & 13.50 & 9.95 & 34.91 & 9.72 & 11.17 \\
\hline $2007 / 08$ & 11.87 & 10.56 & 12.55 & 10.95 & 13.61 & 10.12 & 34.48 & 9.96 & 11.35 \\
\hline $2008 / 09$ & 12.00 & 10.62 & 12.77 & 11.13 & 13.80 & 10.35 & 35.64 & 10.20 & 11.67 \\
\hline $2009 / 10$ & 12.29 & 10.60 & 12.98 & 11.28 & 13.97 & 10.73 & 37.13 & 10.47 & 11.96 \\
\hline
\end{tabular}

Source: Author's computation from Economic Survey (various issues), Government of Nepal(GON). 


\section{References}

Bhagwati, J. N., \& Krueger, A. O. (1973). Exchange control, liberalization, and economic development. American Economic Review, 63, 35-46.

Bjorvatn, K. \& Coniglio, N. D.(2007).On the importance of openness for industrial policy design in developing countries. Discussion Paper, Norwegian School of Economics and Business Administration.

Bruton, H. J.(1998). A reconsideration of import substitution. Journal of Economic Literature, 36, 903-936.

Department of Industry (2006). Industrial statistics. Kathmandu: Government of Nepal. Department of Industry (2012). Industrial statistics. Kathmandu: Government of Nepal.

Government of Nepal (The then His Majesty's Government). (1994). Private company kanoon. Kathmandu, Nepal.

Government of Nepal (The then His Majesty's Government) (1987). Industrial policy and industrial development act. Kathmandu: Foreign Investment Promotion Division, Ministry of Industries.

Haque, I. (2007). Rethinking industrial policy. Discussion Paper No. 183. Geneva: United Nations Conference on Trade and Development.

Krueger, A. O. (1980). Trade policy as an input to development. American Economic Review, 70, 288-292.

Ministry of Industry, Commerce and Supplies and Swiss Development Cooperation (GON/SDC). (2002). Industrial policy review. Kathmandu: Government of Nepal.

Ministry of Finance (MOF) (2000-2012). Economic survey (several issues, 2000-2012). Kathmandu: Government of Nepal.

Ministry of Industry. (2010). Industrial policy 2010. Kathmandu: Government of Nepal.

Ministry of Industry. (1992). Industrial policy 1992. Kathmandu: Government of Nepal.

Ministry of Industry. (1987). Industrial policy 1987. Kathmandu: NIDC.

Ocampo, J.A.(2007).Introduction. In United Nations, Industrial development for the $21^{\text {st }}$ century: Sustainable development perspectives (pp.1-4).New York: United Nations.

Pack, H. \& Saggi, K. (2006). The case for industrial policy: A critical survey. Policy Research Working Paper 3839. Washington, DC: World Bank.

Regmi, G.P. (1994). Industrial growth in Nepal: A sectoral and regional analysis. New Delhi: Oxford and IBH Publishing Co.Pvt.Ltd.

Robinson, J.A.(2009).Industrial policy and development: A political economy perspective. Paper Prepared for the World Bank ABCDE Conference in Seoul June 22-24.

Rodrik. D. (2009). Industrial policy: Don't ask why, ask how. Retrieved September, 2011, from www. Investorswords.com.

Shapiro, H.(2007).Industrial policy and growth. DESA Working Paper No.53. 